\title{
A NEW LOCALITY OF THE DEPRESSED RIVER MUSSEL PSEUDANODONTA COMPLANATA (ROSSMÄSSLER, 1835) (BIVALVIA: UNIONIDAE) IN THE WISŁOK RIVER (CARPATHIAN MOUNTAINS)
}

\author{
MACIEJ BONK
}

\begin{abstract}
Institute of Nature Conservation, Polish Academy of Sciences, al. A. Mickiewicza 33, 31-120 Cracow, Poland (e-mail: bonk.maciej@gmail.com); (i) https://orcid.org/0000-0003-4093-2542

ABSTRACT: This contribution describes two new sites of the depressed river mussel Pseudanodonta complanata (Rossmässler) in the Carpathian Mts. Empty but well preserved shells were found at two sites in the Wisłok River (Krosno and Odrzykoń). These are the second records of the species from the Polish part of the Carpathians. As only empty shells were found, it is unclear whether the species is a constant component of the river fauna of the Carpathians in Poland.
\end{abstract}

KEY WORDS: Pseudanodonta complanata, Unionidae, Carpathians

The depressed river mussel Pseudanodonta complanata (Rossmässler, 1835) is a large unionid. It can be confused with some other members of the family, especially with Anodonta anatina (Linnaeus, 1758). The rhomboid-shaped shell is distinctly laterally flattened (hence the species' name). The colouration is usually greenish-brown. The umbo has a spiny relief unlike the similar species of Anodonta occurring in Poland (PIECHOCKI \& WAWRZYNIAK-WYDROWSKA 2016). The depressed river mussel is in general a riverine species (WOLFF 1968), preferring large rivers (PIECHOCKI \& WAWRZYNIAK-WYDROWSKA 2016), however it is also known from stagnant waters such as postglacial lakes (STAŃCZYKOWSKA et al. 1983), oxbow lakes (JAKUBIK \& LEWANDOWSKI 2013) and dam reservoirs (JURKIEWICZ-KARNKOWSKA 1989). In Poland it is regarded as a lowland species, and only one submontane record from the Carpathians is known from the Dunajec River near Rożnów Reservoir (ZAJĄC 2004, ZAJĄC K. pers. comm.). Other localities include the Wielkopolska region (KorALEWSKA-BATURA et al. 2010), Masurian Lakeland (Krutynia River; JAKUBIK \& LEWANDOWSKI 2011, LEWANDOWSKI \& JAKUBIK 2014), middle and lower Odra River (ZAJĄC 2004). As in other unionids, the larvae are parasites of fish including common species such as Gymnocephalus cernua (Linnaeus, 1758), Perca fluviatilis (Linnaeus, 1758), Pungitius pungitius (Linnaeus, 1758), Gasterosteus aculeatus (Linnaeus, 1758) and Salmo trutta fario (Linnaeus, 1758) (BERRIE \& BOIZE 1985, MCIVOR \& ALDRIDGE 2007, PIECHOCKI \& WAWRZYNIAK-WYDROWSKA 2016 and papers cited therein). The depressed river mussel is generally widespread across European countries. Its range includes Germany, the United Kingdom, Sweden, Finland, Austria, Switzerland, France and the Netherlands (HAAS 1969, MCIVOR \& ALDRIDGE 2007, LOPES-LIMA et al. 2017). Despite its relatively wide range, the species is usually rare (declining in Europe; IUCN 2018) and is listed as Vulnerable (VU) in the IUCN Red List (IUCN 2018). In Poland it is evenly distributed across the lowlands, however many of the records are considered historical and the most recent sites are aggregated in relatively small areas, suggesting a highly fragmented (meta)population within the country (ZAJĄC 2004). The depressed river mussel is also considered the rarest unionid species in Poland (PIECHOCKI \& 


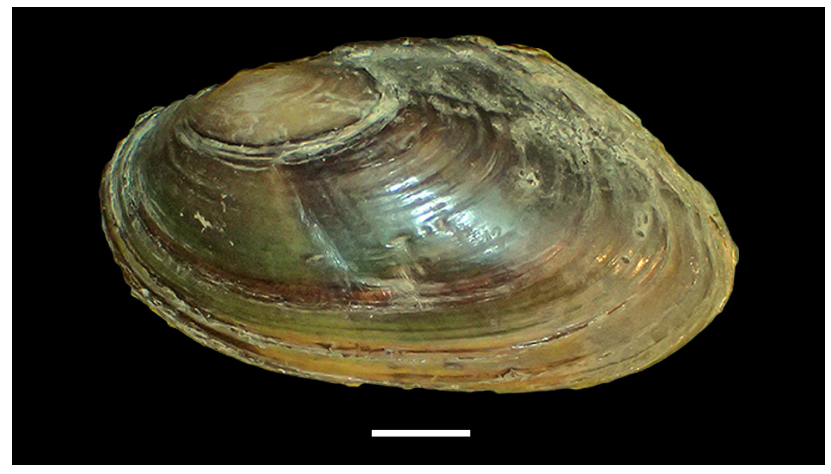

Fig. 1. Shell of Pseudanodonta complanata (Rossmässler, 1835) from the Wisłok river in Krosno. Scale bar $10 \mathrm{~mm}$

WAWRZYNIAK-WYDROWSKA 2016). It is listed in the Polish Red Data Book of Animals as Endangered (EN; ZAJĄC 2004) and legally protected. This contribution describes two new sites of the species from the Wisłok river (Carpathian Mts).

The mussels were detected incidentally during crayfish inventories in Carpathian rivers. Fieldwork was based on visual search at night using torches. On 28.08.2018 and 07.09.2018, two $200 \mathrm{~m}$ sections of the Wisłok river were searched. The water level was low at this time (according to www.pogodynka.pl), with no disrupting water turbidity. Empty shells were collected and taken for identification. Empty shells including specimens with both valves connected with ligament were found at two sites: Krosno: $49^{\circ} 41^{\prime} 14.25^{\prime \prime} \mathrm{N}, 21^{\circ} 47^{\prime} 6.33^{\prime \prime} \mathrm{E}, 267 \mathrm{~m}$ a.s.l., (three specimens) and Odrzykoń: $49^{\circ} 44^{\prime} 20.86^{\prime \prime} \mathrm{N}$, $21^{\circ} 43^{\prime} 20.39^{\prime \prime} \mathrm{E}, 249 \mathrm{~m}$ a.s.l. (four specimens). No live specimens were found, however; in the first site a viable population of the thick-shelled river mussel Unio crassus (Philipsson, 1788) was found, and in Odrzykon the thick-shelled river mussel and Unio tumidus (Philipsson, 1788) were present. In both sites, shells of the depressed river mussel were $5+$ years old (Fig. 1). The sites represent typical submontane Carpathian rivers (Fig. 2). The river width is $12 \mathrm{~m}$ in Krosno and $15 \mathrm{~m}$ in Odrzykoń. In both sites the river is ripraped, however parts of the examined sections remain semi-natural or have spontaneously re-naturalised. The substratum of the river bed within these sites consists mostly of stones and gravel, with sand patches and organic matter deposits. Vegetation is poor and consists mostly of Potamageton species and water mosses. Despite similar control with similar effort of another section of the Wisłok river in Besko and the Sieniawa-Besko Reservoir, no other depressed river mussels were found.

In Poland, as well as in other parts of its range, the depressed river mussel is rare in the mountains or submontane areas. However, it reaches upland and mountainous regions in Europe (LOPES-LIMA et al. 2017), for example in the Carpathian parts of the Tisa River in Ukraine (SÁRKÁNY-KISS 1999). The sites described in this study are the second depressed river mussel localities from the Polish part of the Carpathians. It is uncertain whether the population in the Wisłok river is stable. Notably, records of empty shells may indicate a population that is already extinct, as shells may be preserved in water for decades. Moreover, the presence of the species may be a result

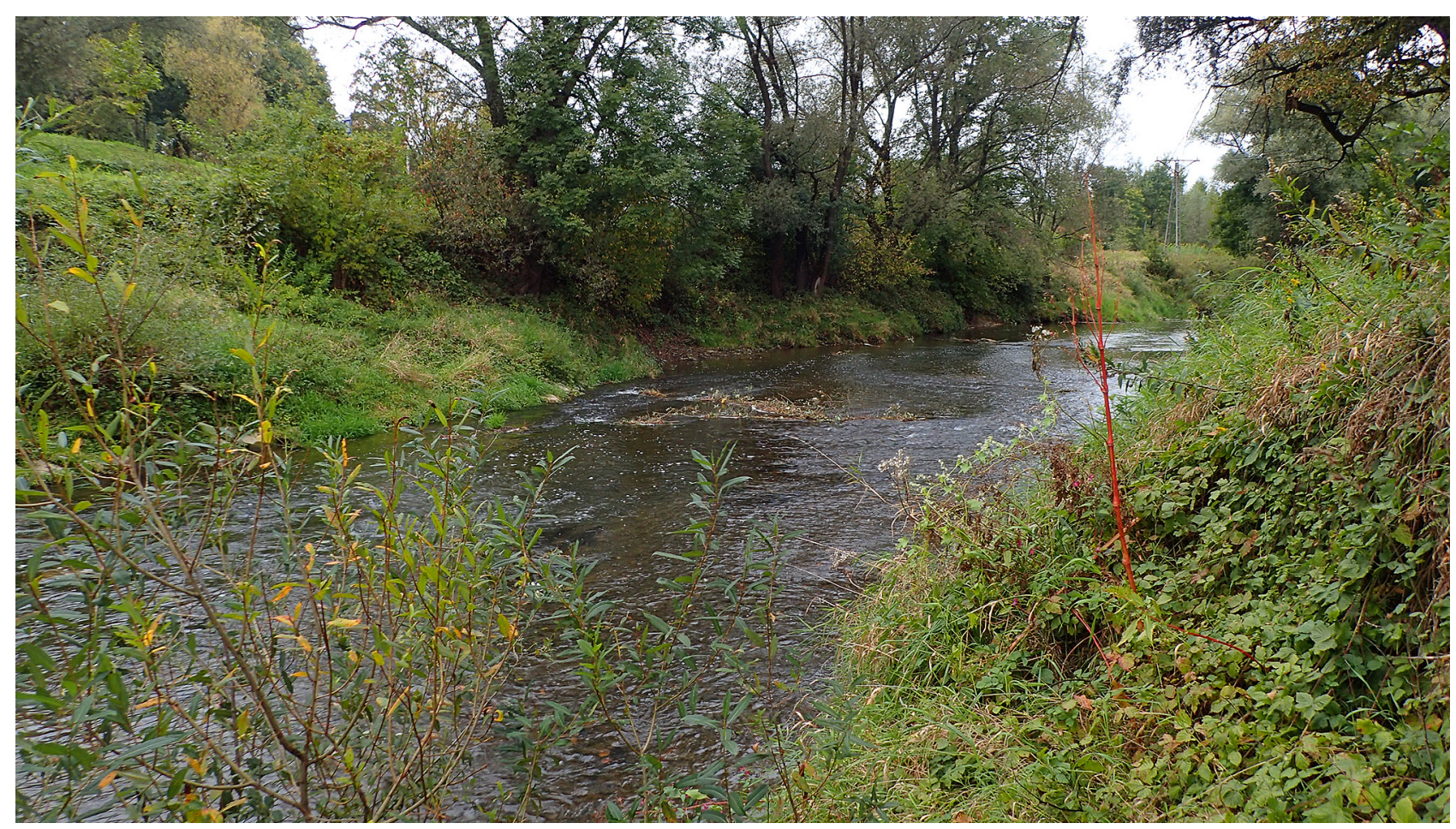

Fig. 2. Habitat of Pseudanodonta complanata (Rossmässler, 1835) in the Wisłok river near Krosno 
of a single, occasional colonisation, as glochidia of the species may be spread by fish. The mussels may have colonised the Wisłok river naturally and/or by introduction of larvae-carrying fish. On the other hand, the depressed river mussel is sensitive to water pollution and low water quality in general (ZAJĄC 2004, PIECHOCKI \& WAWRZYNIAK-WYDROWSKA 2016 and papers cited therein) which is a probable reason for the disappearance of the species from several localities in Poland (LEWANDOWSKI \& STAŃCZYKOWSKA 1975, PIECHOCKI 1981, JURKIEWICZ-KARNKOWSKA 1989, 1998, 2001, LEWANDOWSKI 1991, ZAJĄC 2004). Thus, the empty shells recorded in the Wisłok may be the consequence of mortality associated with pollution episodes. In such case, future colonisation of the area is possible. Adult depressed river mussels live almost entirely buried in the sediments with only siphons visible. This habit makes the species difficult to detect without thorough field surveys; the fieldwork in this study was not aimed at mollusc detection and thus the observations remain anecdotal. Further mollusc-oriented investigations of the Wisłok and similar rivers in the Carpathians could answer the question whether the depressed river mussel is a constant component of the Carpathian fauna.

\section{ACKNOWLEDGEMENTS}

I would like to thank to RAFAE BOBREK for his help in field work and to KATARZYNA ZAJĄC for verification of species identification. Studies on crayfish in the Carpathians were supported by the Institute of Nature Conservation, Polish Academy of Sciences, through its statutory fund and a grant for young scientists and Ph.D. candidates.

\section{REFERENCES}

Berrie A. D., BoIze B. J. 1985. The fish hosts of Unio glochidia in the River Thames. Verhandlungen der Internationalen Vereinigung für Theoretische und Angewandte Limnologie 22: 2712-2716.

HAAS F. 1969. Superfamily Unionacea. Das Tierreich vol. 88. Walter de Gruyter \& Co., Berlin.

IUCN 2018. The IUCN Red List of threatened species. Version 2018-2. Available online at http://www.iucnredlist.org (accessed 17 January 2019).

JAKUBIK B., LEWANDOWSKI K. 2011. Molluscs of the Krutynia River (Masurian Lakeland). Folia Malacologica 19: 19-29. https://doi.org/10.2478/v10125-0110003-X

JAKUBIK B., LEWANDOWSKI K. 2013. Malacofauna in oxbow lakes of the Bug River within the Nadbużański Landscape Park. Teka Komisji Ochrony i Kształtowania Środowiska Przyrodniczego - OL PAN 10: 132-142.

JURKIEWICZ-KARNKOWSKA E. 1989. Occurence of mollusc in the littoral zone of the Zegrzyński Reservoir and premouth and mouth zones of supplying rivers. Ekologia Polska 37: 319-336.

JURKIEWICZ-KARNKOWSKA E. 1998. Long-term changes in mollusc communities in shallow biotopes of a lowland reservoir (Zegrzynski reservoir, central Poland). Polish Journal of Ecology 46: 43-63.

JURKIEWICZ-KARNKOWSKA E. 2001. Zbiornik Zegrzyński jako jeden $z$ ważniejszych obszarów dla ochrony różnorodności biologicznej na Mazowszu. In: KOT H., DOMBROWSKI A. (eds). Strategia ochrony fauny na Nizinie Mazowieckiej. Mazowieckie Towarzystwo Ochrony Fauny, Siedlce, pp. 159-168.

KorAlEWSKA-BATURA E., GOŁDYN B., SZYBIAK K., BŁOSZYK J. 2010. Materials to the knowledge of molluscs of Wielkopolska. II. Checklist. Folia Malacologica 18: 2941. https://doi.org/10.2478/v10125-010-0004-1

LEWANDOWSKI K. 1991. Long-term changes in the fauna of family Unionidae bivalves in the Mikołajskie Lake. Ekologia Polska 39: 265-272.

LEWANDOWSKI K., JAKUBIK B. 2014. Małże z rodziny skójkowatych (Unionidae) w systemie rzeczno-jeziornym Krutyni (Pojezierze Mazurskie). Chrońmy Przyrodę Ojczystą 70: 423-430.

LEWANDOWSKI K., STAŃCZYKOWSKA A. 1975. The occurrence and role of bivalves of the family Unionidae in Mikołajskie Lake. Ekologia Polska 23: 317-334.

LOPES-LiMA M., SOUSA R., GEIST J., AldRIDGE D. C., ARAUJO R., BERGENGREN J., BESPALAYA Y., BÓDIS E., BURLAKOVA L., VAN DAMme D., DOUdA K., Froufe E., GEORGIEV D., Gumpinger C., KaratayeV A., KebapÇI Ü., KilleEN I. LAJTNER J., LARSEN B. M., LAUCERI R., LEGAKIS A., LOIS S., Lundberg S., MoOrKens E., MotTe G., NAGEL K., Ondina P., OUteIro A., PAUNOVIC M., PRIÉ, V., VON Proschwitz T., RicCARdi N., RUDZĪTE M., RudZītis M., SCHEDER C., SEDDON M., ŞEREFLIȘAN H., SimiĆ V., SOKOlOVA S., STOECKL K., TASKINEN J., TEIXEIRA A., THIELEN F., TRICHKOVA T., VARANDAS S., VICENTINI H., ZAJĄC K., ZAJĄC T., ZOGARIS S. 2017. Conservation status of freshwater mussels in Europe: state of the art and future challenges. Biological Reviews of the Cambridge Philosophical Society 92: 572-607. https:// doi.org/10.1111/brv.12244

MCIVOR A. L., AldRidge D. C. 2007. The reproductive biology of the depressed river mussel, Pseudanodonta complanata (Bivalvia: Unionidae), with implications for its conservation. Journal of Molluscan Studies 73: 259266. https://doi.org/10.1093/mollus/eym023

PIECHOCKI A. 1981. Współczesne i subfosylne mięczaki (Mollusca) Gór Świętokrzyskich. Habilitation Thesis, Acta Universitatis Lodziensis, Łódź.

PIECHOCKI A., WAWRZYNIAK-WYDROWSKA B. 2016. Guide to freshwater and marine Mollusca of Poland. Bogucki Wydawnictwo Naukowe, Poznań. 
SÁRKÁNY-KISS A. 1999. A study of aquatic molluscs in the Upper Tisa. In: HAMAR J., SÁRKÁNY-KISS A. (eds). The Upper Tisa Valley Preparatory proposal for Ramsar site designation and an ecological background Hungarian, Romanian, Slovakian and Ukrainian co-operation. Tiscia monograph series. Tisza Klub \& Liga Pro Europa, Szeged, pp. 409-412.

STAŃCZYKOWSKA A., LEWANDOWSKI K., EJSMONT-KARABIN J. 1983. Biotic structure and processes in the lake system of River Jorka watershed (Masurian Lakeland, Poland). IX Occurrence and distribution of molluscs with special consideration to Dreissena polymorpha (Pall.). Ekologia Polska 31: 761-780.

WOLFF W. I. 1968. The Mollusca of the estuarine region of the rivers Rhine, Meuse and Scheldt in relation to the hydrography of the area. I. The Unionidae. Basteria 32: $13-47$.

ZAJĄC K. 2004. Pseudanodonta complanata (Rossmässler, 1835). In: GŁOWACIŃSKI Z., NOWACKI J. (eds). Polska Czerwona księga Zwierząt. Bezkręgowce. Instytut Ochrony Przyrody PAN, Kraków. Available online at http://www.iop.krakow.pl/pckz/opis6113-2.htm1 ? $i d=129 \& j e=p l$ (accessed 15 January 2019).

Received: January 1st, 2019

Revised: January 17th, 2019

Accepted: January 18th, 2019

Published on-line: March 19th, 2019 